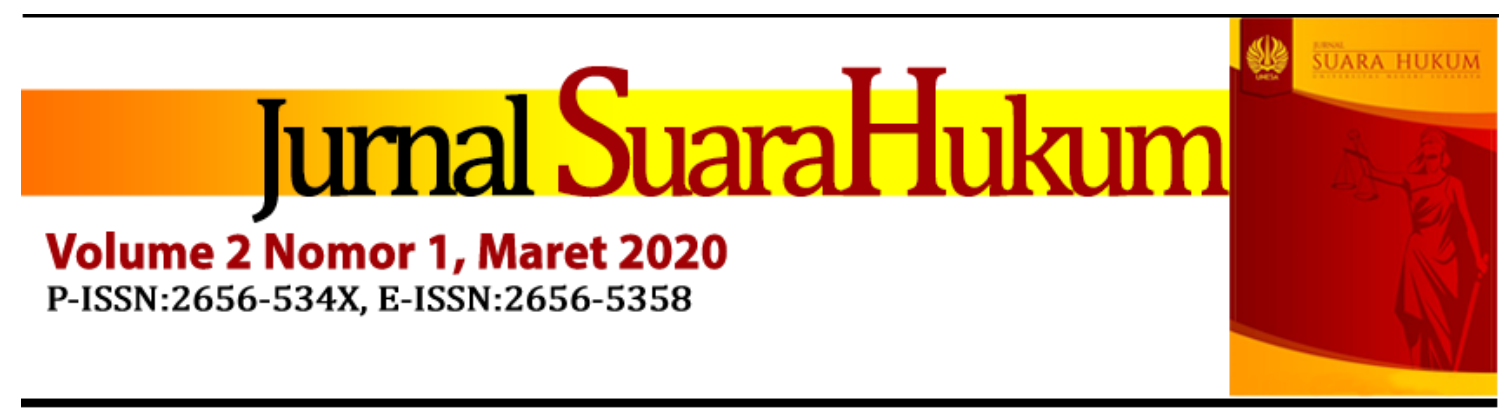

\title{
Pemberlakuan Pajak terhadap Barang Hasil Transaksi Jasa Titip Online
}

\author{
Usamah Rievzqy Ahmad \\ Fakultas Hukum, Universitas Indonesia, Depok, Indonesia, \\ ahmadrievzqy@gmail.com
}

\begin{abstract}
As time goes by, technologies are developing more and more. One of a result of it that we know is internet. Internet is a network that enable to connect every human being in all over the world. Internet gave us many positive impacts, to fulfil our daily needs is one of them. Thanks to internet we can do our business activities more effective. One of the business activites that we can do is vending, selling things by internet known as online shopping. Many people can sell anything through online shopping such as goods and services. They called "Jasa Titip Online", is one type of a business that let consumer told us what they want to and then we look and buy goods that consumers want. "Jasa Titip Online" devided into two kinds, first is domestic purchases and the second is overseas purchases. Problems arise from the overseas purchases, person who conduct "Jasa Titip Online" must collect things from other country then bring it to Indonesia. That will create new competitors for large companies involved in the export-import business. Goods that sold by export-import companies supposed to be taxed when entering Indonesian territory. However same things didn't happen to a person who commit "Jasa Titip Online", it should be taxed to create fair business competition. The tax provisions currently in force are stated in Peraturan Menteri Keuangan No. 203 Tahun 2017 that define imported goods brought by a person for personal purposes that worth under US\$500 will be free on board. That provisions are less effective due to more people conduct "Jasa Titip Online" that somehow brought things more than US\$ 500 but still free on board.
\end{abstract}

Keywords: Technology, Internet, Online Shopper, Jasa Titip Online, Taxes

\section{Pendahuluan}

Pada era globalisasi saat ini berbagai aspek kehidupan masyarakat banyak dipengaruhi oleh kemajuan teknologi informasi dan komunikasi. Perkembangan dunia teknologi semakin maju dan memiliki banyak inovasi. Perkembangan teknologi dan penyebaran informasi yang sangat pesat, telah membawa perubahan besar dalam tatanan masyarakat, baik secara global maupun 
nasional, termasuk Indonesia. Media sosial seperti Facebook, Twitter, Instagram, Line, WhatsApp, dan lain-lain ini berperan besar dalam perubahan sosial masyarakat. Salah satu perubahan besar dalam masyarakat Indonesia adalah perubahan perilaku masyarakat yang secara sadar-tidak sadar berubah menjadi masyarakat komsumtif. Ternyata perilaku komsumtif masyarakat Indonesia sudah terlihat sejak tahun 1970-an, bahkan pada saat krisis ekonomi global melanda dunia di tahun 1998 dan 2008, Indonesia seolah tidak terpengaruh. Nilai belanja masyarakatnya meningkat cukup signifikan. Tidak saja di dalam negeri, namun juga di luar negeri. Dan di era 2000an ini, kehidupan konsumtif masyarakat Indonesia semakin menjadi-jadi. Tidak heran jika Negara Tercinta kita ini menjadi daya tarik dan sasaran bombardir barang dan produk dari berbagai dunia. Karena sudah dapat dipastikan produk apapun yang masuk Indonesia akan laris bak kacang goreng, mulai dari produk berkualitas paling rendah hingga paling tinggi sekali pun. ${ }^{1}$

Adanya telepon genggam canggih dan berbagai fasilitas pendukung lainnya menambah kemudahan bagi masyarakat dalam berintraksi maupun mencari sesuatu yang dioinginkan. Kegiatan bisnis yang pada umumnya dilakukan secara konvensional mulai perlahan beralih secara elektronik dan menggunakan jaringan-jaringan komputer yaitu dengan menggunakan internet yang dikenal dengan istilah E-Commerce. ${ }^{2}$ Perilaku konsumtif masyarakat terhadap produk luar negeri ini didukung oleh menjamurnya E-Commerce yang menawarkan produk luar negeri dengan harga yang lebih murah. Perkembangan toko online atau yang sering disebut Online Shop melalui media internet sudah menjamur di Indonesia, bahkan sudah sangat dikenal baik oleh khalayak ramai. Banyaknya beragam kemudahan dalam berbelanja dan bermacam jenis produk dan jasa yang ditawarkan, membuat masyarakat

\footnotetext{
${ }^{1}$ Kompasiana Chandra Mulyadi (2014), 10 Peringkat Indonesia di Dunia. https://www.kompasiana.com/mulyady1688/54f934b0a333112c048b4a1a/10-peringkat-indonesia-didunia. [Accessed October 15 2019]

${ }^{2}$ Abdul Halim (2005), Bisnis E-Commerce, Yogyakarta: Pustaka Pelajar, halaman 10
} 
Indonesia menjadikan Online Shop sebagai salah satu tempat dalam melakukan transaksi jual beli selain pusat perbelanjaan konvensional. Hal tersebut membuat banyak pelaku usaha Online Shop bermunculan menawarkan produknya dengan berbagai cara untuk menarik konsumen berbelanja.

Menjamurnya sistem belanja online memunculkan peluang bisnis baru yang salah satunya oleh masyarakat dikenal sebagai jasa titip. Jasa titip adalah sebuah pekerjaan keluar masuk toko, mall atau pedagang besar dengan beberapa brand tertentu sesuai dengan keinginan para pelanggan yang percaya pada jasa mereka. Barang yang dicari tidak hanya ditingkat lokal saja, tidak jarang ada permintaan untuk barang-barang dari luar negeri. ${ }^{3}$ Profesi jasa titip prinsipnya sederhana, pelaku yang menawarkan jasanya dapat dikatakan menjadi pihak ketiga antara penjual barang dan pembeli barang. Pada dasarnya kegiatan yang dilakukan pelaku usaha jasa titip ini adalah membeli produk di tempat dan brand tertentu sesuai dengan pesanan yang kemudian nantinya barang tersebut diberikan kepada pembeli dan pelaku jasa titip nantinya mendapatkan upah atau imbalan sebagai tarif jasa pembelian barang tersebut. Salah satu resiko bagi pengguna jasa titip atau pembeli yang membeli barang melalui jasa titip yaitu resiko rusak atau cacat barang yang nantinya akan diterima si pembeli. Karena dalam transaksi jual beli jasa titip ini pelaku jasa titip bukanlah pemilik barang yang diperjual belikan tersebut jadi jika barang yang diterima terjadi kerusakan atau cacat maka barang tersebut tidak dapat dikembalikan atau ditukar dengan barang lainnya sejenis.

Jasa titip dapat dilakukan untuk pembelian dalam negeri maupun luar negeri. Namun biasanya pengguna jasa titip membeli barang yang berasal dari luar negeri. Jasa titip berbeda dengan barang impor, barang impor adalah barang yang melalui proses transportasi barang dari suatu negara ke negara lain secara legal, biasanya dalam proses perdagangan. ${ }^{4}$ Perbedaan antara barang yang

\footnotetext{
3 Bisnis Indonesia, (2017), https://koran.bisnis.com/read/20170614/432/662322/jasa-titip, [Accessed October 4 2019]

${ }^{4}$ Amir, (1996), Ekspor-Impor, Jakarta: Pustaka Binaman Pesindo, halaman 43
} 
diperoleh melalui impor dengan jasa titip terletak pada jumlah barang yang masuk ke dalam negeri dan pelakunya, dalam jasa titip kegiatan tersebut dilakukan oleh individu atau perorangan dan sedangkan barang impor dilakukan oleh perusahaan khusus yang bergerak pada bidang ekspor maupun impor. ${ }^{5}$ Jual beli secara online pada prinsipnya adalah sama dengan jual beli secara konvensional. Pembedanya hanya pada penggunaan sarana internet atau sarana telekomunikasi lainnya. Akibatnya adalah dalam transaksi jual beli secara online sulit dilakukan eksekusi ataupun tindakan nyata apabila terjadi sengketa maupun tindak pidana penipuan. Sifat siber dalam transaksi secara elektronik memungkinkan setiap orang baik penjual maupun pembeli menyamarkan atau memalsukan identitas dalam setiap transaksi maupun perjanjian jual beli. ${ }^{6}$

Ubi Socitas Ibi Ius adalah salah satu istilah yang ada dalam hukum, yang artinya adalah dimana ada masyarakat disitu ada hukum. Hukum selalu mengikuti perkembangan masyarakat untuk melindungi kepentingankepentingan yang perlu dijaganya, yaitu kepentingan negara, hukum, dan masyarakat. Perubahan pada masyarakat, membuat perubahan pada hukum pula, untuk melindungi kepentingannya, hukum akan mengeluarkan, mecabut, atau mengubah ketentuan-ketentuan yang ada untuk menyelaraskan dengan perubahan kebutuhan masyarakat. Di Indonesia perkembangan transaksi dalam jual beli secara online telah diatur dalam Undang-Undang Informasi dan Teknologi Elektronik dan Peraturan Pemerintah tentang Penyelenggaraan Sistem Transaksi Elektronik harus dapat dipertanggungjawabkan. Sahnya suatu perjanjian elektronik dan hal-hal yang harus ada dalam transaksi jual beli online secara jelas diatur dalam peraturan tersebut.

Dalam perkembangannya transaksi jual beli online telah diatur dalam Undang-Undang Nomor 11 Tahun 2008 tentang Informasi dan Teknologi Elektronik (UU ITE) dan Peraturan Pemerintah Nomor 82 Tahun 2012 tentang

\footnotetext{
${ }^{5}$ Sugianto, (2008), Pengantar Kepabeanan dan Cukai, Jakarta: Cikal Sakti, halaman 173

${ }^{6}$ Hukum Online, (2018), https://www.hukumonline.com/klinik/detail/lt50bf69280b1ee/perlindungankonsumen-dala-e-commerce/, [Accessed October 4 2019]
} 
Penyelenggaraan Sistem dan Transaksi Elektronik. Transaksi elektronik memerlukan persetujuan atas syarat dan ketentuan, sebuah transaksi secara online dianggap sah apabila7:

1. Terdapat kesepakatan para pihak

2. Dilakukan oleh subjek hukum yang cakap atau yang berwenang mewakili sesuai dengan peraturan perundang-undangan.

3. Objek transaksi tidak boleh bertentangan dengan peraturan perundang-undangan, kesusilaan dan ketertiban umum.

Hal-hal yang harus dimuat dalam transaksi jual beli secara online adalah sebagai berikut ${ }^{8}$ :

1. Identitas para pihak

2. Objek dan spesifikasi

3. Persyaratan transaksi elektronik

4. Harga dan biaya

Berdasarkan uraian diatas penulis tertarik mengenai bagaimana pengaturan terhadap jasa titip online, terutama dalam sistem perpajakan. Bagaimana sistem penerapan pajak terhadap pelaku usaha yang bergerak dibidang jasa titip online tersebut.

\section{Metode Penelitian}

Jenis penelitian ini adalah yuridis normatif. Sebagai penelitian normatif, penelitian ini menitikberatkan pada studi kepustakaan yang berdasarkan pada data sekunder. Pendekatan yuridis sendiri adalah suatu pendekatan yang mengacu pada hukum dan peraturan perundang-undangan yang berlaku. Data sekunder yang digunakan meliputi:

a. Bahan hukum primer yaitu bahan hukum yang mengikat berupa peraturan perundang-undangan yang berhubungan dengan sistem transaksi

\footnotetext{
${ }^{7}$ Peraturan Pemerintah Nomor 82 Tahun 2012 tentang Penyelenggaraan Sistem dan Transaksi Elektronik, Pasal 47 ayat (2)

${ }^{8}$ Ibid, Pasal 48 ayat (3)
} 
elektronik dan perpajakan, yaitu Undang-Undang Nomor 11 Tahun 2008 tentang Informasi dan Transaksi Elektronik, Peraturan Pemerintah Nomor 82 Tahun 2012 tentang Penyelenggaraan Sistem dan Transaksi Elektronik, Undang-Undang Nomor 16 Tahun 2009 tentang Ketentuan Umum dan Tata Cara Perpajakan (KUP), Undang-Undang Nomor 36 Tahun 2009 tentang Pajak Penghasilan, Peraturan Menteri Keuangan Nomor 203/PMK.04/2017 tentang Ketentuan Ekspor dan Impor Barang Yang Dibawa Oleh Penumpang dan Awak Sarana Pengangkut.

b. Bahan hukum sekunder yaitu buku teks yang berisi mengenai prinsip dasar ilmu hukum dan pandangan-pandangan klasik para sarjana yang mempunyai kualifikasi tinggi berupa tulisan-tulisan ilmiah, buku-buku, artikel dan hasil penelitian

\section{Pembahasan}

Perkembangan teknologi informasi dewasa ini semakin intensif didukung dengan infrastruktur penunjang yang telah dibangun oleh pemerintah maupun swasta. Seiring dengan perkembangan tersebut teknologi informasi saat ini telah mengakibatkan berkembangnya sektor perdagangan menjadi elektronik. Teknologi informasi merupakan bentuk teknologi yang digunakan untuk menciptakan, menyimpan mengubah dan menggunakan informasi dalam segala bentuknya. Melalui pemanfaatan teknologi informasi ini, perusahaan mikro, kecil, maupun menengah dapat memasuki pasar global. Perusahaan yang awalnya kecil seperti Amazon, Yahoo, Ebay, ketiga perusahaan tersebut menjadi raksasa dalam waktu singkat hanya karena pemanfaatan teknologi informasi dalam pengembangan usahanya. ${ }^{9}$

Dalam memenuhi kebutuhan sehari-hari, sangat memungkinkan bagi beberapa orang untuk memilih menempuh cara yang lebih instan dalam memperoleh barang tertentu. Pemenuhan kebutuhan secara instan tesebut

\footnotetext{
9 Suyanto Muhammad, (2003), Strategi Periklanan pada E-commerce Perusahaan Top Dunia, Yogyakarta: Penerbit Andi
} 
diikuti dengan semakin berkembangnya zaman yang ditandai dengan perkembangan media internet. Pada saat ini sudah banyak orang yang menjadikan media internet sebagai salah satu jalan untuk memperoleh kebutuhannya, seperti membeli barang tertentu hingga membuka peluang usaha secara online. Online shop merupakan suatu tempat untuk menjual barang dan/atau jasa melalui internet, konsumen dapat melihat foto-foto atau bahkan video terkait dengan barang yang diperdagangkan oleh online shop tertentu melalui internet. ${ }^{10}$ Dalam hal ini tentunya terjadi pergeseran budaya dalam berbelanja. Hal tersebut ditandai dengan adanya perubahan cara yang pada awal mulanya dilakukan secara konvensional yaitu secara tatap muka, menjadi digital yaitu melalui internet. Sistem belanja online ini bisa juga disebut dengan electronic commerce (e-commerce). E-commerce merupakan suatu konsep yang bisa digambarkan sebagai proses jual beli barang dan/atau jasa pada internet atau proses jual beli atau pertukaran produk, jasa, dan informasi melalui jaringan informasi termasuk internet. ${ }^{11}$ Secara singkat sejarah dari e-commerce bermula pada tahun 1970 dengan adanya inovasi semacam electronic fund transfer (EFT). Saat itu tingkat aplikasinya masih terbatas pada besar, lembaga keuangan, dan segelintir perusahaan kecil yang nekat lalu muncul electronic data interchange (EDI), yang berkembang dari transaksi keuangan ke pemrosesan transaksi lain serta memperbesar jumlah perusahaan yang berperan serta, mulai lembagalembaga keuangan hingga perusahaan manufaktur, ritel, layanan dan sebagainya. Aplikasi lainnya kemudian bermunculan yang memiliki jangkauan dari perdagangan saham hingga sistem reservasi perjalanan. Pada saat itu siste tersebut disebut sebagai aplikasi telekomunikasi yang nilai strategisnya sudah dikenal secara umum. Dengan adanya komersialisasi internet di awal tahun 1990, serta pesatnya pertumbuhan yang mencapai hingga jutaan pelanggan

\footnotetext{
10 Chacha Andira Sari, (2015), Perilaku Berbelanja Online di Kalangan Mahasiswi Antropologi Universitas Airlangga, Surabaya: Skripsi Fakultas Ilmu Sosial dan Ilmu Politik Universitas Airlangga http://journal.unair.ac.id/download-fullpapers-auna97cbdaabbfull.pdf

${ }^{11}$ Prasetyo Budi Widagdo, (2016), Analisis Perkembangan E-Commerce Dalam Mendorong Pertumbuhan Ekonomi Wilayah di Indonesia, Yogyakarta: Fakultas Geografi Universitas Gadjah Mada
} 
potensial, maka muncul istilah electronic commerce. ${ }^{12}$ Pemanfaatan teknologi informasi dalam menjalankan bisnis perdagangan atau sering dikenal dengan istilah e-commerce bagi perusahaan kecil dapat memberikan fleksibilitas dalam produksi, memungkinkan pengiriman ke pelanggan secara lebih cepat dan hemat, serta mendukung transaksi cepat tanpa kertas.

Jual beli secara online dapat mengefektifkan dan mengefisiensikan waktu sehingga seseorang dapat melakukan transaksi jual beli dengan setiap orang dimanapun dan kapanpun. Semua transaksi jual beli melalui internet ini dilakukan tanpa ada tatap muka antara para pihak, mereka mendasarkan transaksi jual beli tersebut atas rasa kepercayaan satu sama lain sehingga perjanjian jual beli yang terjadi diantara para pihak pun dilakukan secara elektronik. ${ }^{13}$ Melalui e-commerce semua formalitas-formalitas yang biasa digunakan dalam transaksi konvensional dikurangi, di samping tentunya konsumen pun memiliki kemampuan untuk mengumpulkan dan membandingkan informasi seperti barang dan jasa secara lebih leluasa tanpa dibatasi oleh batas wilayah (borderless). E-commerce tidak hanya memberikan kemudahan bagi konsumen, namun perkembangan ini memudahkan produsen dalam memasarkan produk yang berpengaruh pada penghematan biaya dan waktu. ${ }^{14}$

Pasal 1 angka 6 UU ITE No. 11 Tahun 2008 mengatur bahwa penyelenggaraan sistem elektronik adalah pemanfaatan sistem elektronik oleh penyelenggara negara, orang, badan usaha, dan/atau masyarakat. Selanjutnya, Pasal 15 ayat (1) UUITE mengatur bahwa setiap penyelenggara sistem elektronik harus menyelenggarakan sistem elektronik secara andal dan aman serta bertanggungjawab terhadap beroperasinya sistem elektronik sebagaimana mestinya. Jual beli secara online (e-commerce) pada dasarnya sama dengan jaul beli pada umumnya, dimana suatu jual beli terjadi ketika ada kesepakatan

\footnotetext{
${ }^{12}$ Ibid

${ }^{13}$ Hemiwati, (2013), Penerapan Pasal 1320 KUHPerdata Terhadap Jual Beli Secara Online (E-Commerce), Jurnal Ipteks Terapan, Vol 8 No 4

${ }^{14}$ Ibid
} 
mengenai barang atau jasa yang diperdagangkan serta harga atas barang atau jasa tersebut. Jual beli secara online dan jaul beli pada umumnya (konvensional) yang membedakan hanya pada media yang digunakan. Jika ada jual beli konvensional para pihak harus bertemu langsung disuatu tempat guna menyepakati mengenai apa yang diperjual belikan serta berap harga atas barang atau jasa tersebut. ${ }^{15}$ Sedangkan pada jual beli secara online (e-commerce), proses transaksi yang terjadi memerlukan sutu media internet sebagai media utamanya, sehingga proses transaksi perdagangan terjadi tanpa perlu adanya pertemuan langsung atau face to face antar para pihak. Proses transaksi tawar menawar harga dapat dilakukan dimana saja tanpa harus mempertemukan pihak penjual dan pembeli di dalam suatu tempat yang sama untuk menyepakati harga dari suatu barang. ${ }^{16}$

Perkembangan teknologi informasi terutama internet menciptakan sebuah ruang virtual dan menggantikan ruang fisik. Melalui ruang virtual inilah kegiatan e-commerce terjadi, meskipun dalam beberapa bagian sistemnya tetap menggunakan ruang fisik. Dengan semakin berkembangnya kemajuan online shop di Indonesia, semakin banyak pula pelaku usaha yang bermunculan yang mengambil celah-celah dalam membuka bisnis melalui internet. Berbagai media sosial seperti instagram, facebook, dan lain-lain yang bermunculan menjadikan ladang bagi para pelaku usaha untuk berbisnis. Terdapat beberapa istilah dalam jual beli secara online salah satunya adalah jasa titip online. Bisnis jasa titip beli online ini biasa dipasarkan melalui media online, salah satunya melalui media jejaring sosial seperti instagram, dan whatsapp yang dipilih untuk digunakan sebagai media promosi, sebab penggunaan jejaring sosial media, khususnya instagram tersebut dinilai cukup menguntungkan jika dijadikan sebagai media promosi dan perdagangan barang yang mana dapat dilihat dari pengguna aplikasi jejaring sosial media instagram yang cukup banyak, sehingga dapat memperluas pemasaran dan dapat dilakukan kapanpun, dimanapun selama

\footnotetext{
${ }^{15} \mathrm{Ibid}$

${ }^{16} \mathrm{Ibid}$
} 
terdapat jaringan internet, serta keuntungan yang lebih besar adalah untuk memangkas biaya pengeluaran, karena hanya pengeluaran biaya untuk membeli data internet saja. Akun instagram merupakan salah satu yang digunakan untuk media promosi untuk bisnis jasa titip online tersebut. Adanya keinginan untuk memanfaatkan hobi berbelanjanya sebagai bisnis yang menghasilkan keuntungan pribadinya juga penggunaan media jejaring sosial yang lebih bermanfaat dan produktif merupakan alasan yang mendasari dibuatnya akun instagram. ${ }^{17}$ Penggunaan media jejaring sosial yang hanya digunakan untuk berbagi kegiatan sehari-hari melalui foto dan video serta untuk melihat fotodan video yang diunggah oleh pengguna jejaring sosial media yang lainsetelah melihat foto-foto yang diunggah oleh pemilik akun instagram, pemesan atau pembeli yang tertarik untuk membeli produk yang ditawarkan akun Instagram akan melakukan pemesanan barang melalui salah satu aplikasi sosial media yaitu berupa WhatsApp.

Mekanisme pada jasa titip online didalam trasaksinya pihak penitip diharuskan mengisi format pemesanan yang telah ditentukan oleh pihak penyedia jasa tititp dan diharuskan untuk membayar terlebih dahulu melalui transfer ke rekening milik penyedia jasa titip tersebut. Setelah itu, pihak yang dititipi akan membelanjakan uang tersebut sesuai dengan pesanan penitip. Namun ketika barang yang diinginkan penitip di toko tersebut ternyata ketersediaan barangnya sudah tidak ada, maka pihak penyedia akan mengembalikan sejumlah uang penitip namun jumahnya tidak sama dengan jumlah awal yang telah dibayarkan oleh pihak penitip. Jumlah yang tidak sama ini dilakukan oleh pihak penitip yang secara tiba-tiba tetap mengambil imbalan upah meskipun ketersedian barangnya kosong. Hal inilah yang tidak dijelaskan diawal pemesanan. ${ }^{18}$ Manfaat adanya proses jual beli pada jasa titip beli online di kalangan masyarakat saat ini sudah terbilang sangat menguntungkan bagi

\footnotetext{
${ }^{17}$ Zurifah Diana Sari, (2018), Analisis Fiqih Muamalah Terhadap Praktik Jasa Titip Beli Online, Surabaya: Skripsi Fakultas Syariah dan Hukum Universitas Islam Negeri Sunan Ampel Surabaya

${ }^{18}$ Ibid
} 
beberapa pihak. Pertama, bagi pihak pembeli atau konsumen sudah jelas sangat memudahkan, jika pembeli adalah seorang yang super sibuk dan tidak sempat untuk pergi berbelanja, sekarang dengan adanya bisnis ini pembeli tidak perlu capek-capek atau mengeluarkan biaya mahal untuk keluar berbelanja, karena dengan duduk manis dan memainkan gadget pun barang sudah bisa dibeli dan sampai ditangan pembeli. ${ }^{19}$ Kedua manfaat yang dirasakan dengan adanya bisnis ini adalah pihak penyedia akun jasa titip beli online ini sendiri, selain bisnis ini tidak memerlukan modal, bisnis ini bisa dibilang sangat menjanjikan keuntungan untuk setiap transaksinya. Karena setiap barang yang ditawarkan untuk dititipbelikan dikenakan imbalan fee atas jasanya tersebut. Ketiga adalah pihak penjual, manfaat yang dirasakan dengan adanya bisnis jasa titip ini adalah sangat dibantu oleh pihak penyedia jasa titip beli dalam hal pemasaran produknya. Karena tidak menutup kemungkinan bahwa pusat-pusat perbelanjaan sekarang ini sudah sepi pengunjung. Karena tidak lain disebabkan karena faktor pembeli itu sendiri.

Jasa titip online sendiri terdiri dari dua jenis barang, yaitu barang dalam negeri dan barang luar negeri. Jasa titip online untuk barang luar negeri berbeda dengan dalam negeri yang hanya tinggal menambahkan menambahkan tariff jasa itu sendiri sedangkan untuk barang luar negeri perlu perhitungan lebih teliti. Hal tersebut karena terdapat biaya yang mungkin akan timbul saat barang yang ditransaksikan dibawa masuk ke Indonesia, sesuai dengan jenis, jumlah, dan harga barang yang dibawa. ${ }^{20}$ Aturan mengenai impor barang yang dibawa penumpang diatur dalam Peraturan Menteri Keuangan Nomor 203/PMK.04/2017 tentang Ketentuan Ekspor Dan Impor Barang Yang Dibawa Oleh Penumpang Dan Awak Sarana Pengangkut, yang mulai berlaku mulai 1 Januari 2018. Poin utama aturan ini adalah pembebasan barang impor bawaan sampai dengan nilai US\$ 500 dari sebelumnya US\$250, dan penghapusan

\footnotetext{
${ }^{19}$ Ibid

20 Forum Ortax Santoso, (2019), Usaha Jasa Titip Harus Bayar Pajak?, https:/ / ortax.org/ortax/?mod=forum\&page=show\&idtopik=79866 [Accessed October 15 2019]
} 
batasan nilai barang untuk keluarga. Sebelum menentukan bagaimana sebaiknya memperlakukan usaha jasa titip ini, hal pertama yang harus dilakukan adalah pastikan kita mempunyai NPWP. Selain untuk mendapatkan tarif Pajak Penghasilan Pasal 22 atas impor 7,5\% dibanding jika tidak ber-NPWP maka dikenakan sebesar 15\%. Dengan ber-NPWP maka atas PPh Pasal 22 impor bisa dikreditkan dalam penghitungan PPh terutang setahun. ${ }^{21}$ Jika seseorang mendaftarkan diri jasa titip sebagai kegiatan usaha utama maka akan dikategorikan sebagai jasa perantara, sehingga dikecualikan dari pengenaan PPh final 0,5\% x omset. Sesuai Pasal 2 ayat (3) dan (4) huruf h Peraturan Pemerintah Nomor 23 Tahun 2018. Untuk omset sampai dengan 4.8 miliar rupiah setahun, penghitungan penghasilan netto menggunakan norma (50\% x Penghasilan Bruto). Jika melebihi 4.8 miliar rupiah, maka diwajibkan melakukan pembukuan (penghasilan bruto - biaya operasional). ${ }^{22}$ Penghasilan netto dikurangi Penghasilan Tidak Kena Pajak (PTKP) untuk menentukan Penghasilan Kena Pajak. Tarif yang digunakan sesuai Pasal 17 UU KUP, bersifat progresif sesuai dengan tingkatan Penghasilan Kena Pajak. Tarif 5\% sampai dengan 50 juta rupiah, 15\% untuk >50 juta s.d 250 juta, 25\% untuk >250 juta s.d 500 juta, dan $30 \%$ untuk diatas 500 juta. ${ }^{23} \mathrm{Hal}$ berbeda terjadi jika jasa titip merupakan usaha sampingan, misalkan telah mempunyai usaha jual beli pakaian atau toko bangunan yang menggunakan tarif PPh UMKM sesuai PP 23 Tahun 2018. Terlebih jika barang-barang titipan harganya tinggi, sementara fee jasa titipnya kecil. Jika menggunakan tarif PPh UMKM 0,5\%, bisa saja malah menjadi pengurang keuntungan dari usaha utama. Sebaiknya dihitung ulang demi menentukan menggunakan pembukuan atau pencatatan biasa, mana yang lebih menguntungkan. Jika nilai barang yang dibawa melebihi US\$ 500, maka kelebihannya dikenakan bea masuk 10\% dan Pajak Dalam Rangka Impor (PDRI).

\footnotetext{
${ }^{21}$ Direktorat Jenderal Pajak Purnadi Anang, (2019), Mudah Menjadi Jasa Titip Profesional, Bagaimana Kewajiban Pajaknya?, $\quad$ https://www.pajak.go.id/id/artikel/mudah-menjadi-jasa-titip-profesional-bagaimanakewajiban-pajaknya. [Accessed October 15 2019]

${ }^{22}$ Ibid

${ }^{23}$ Ibid
} 
PDRI terdiri dari Pajak Pertambahan Nilai (PPN) 10\% dan Pajak Penghasilan (PPh) 7,5\% jika mempunyai NPWP. Jika tidak mempunyai NPWP maka dikenakan tarif lebih tinggi 100\% (PPh 15\%). ${ }^{24}$

Pelaku jasa titip harus pintar menghitung total harga barang yang akan dibawa ke Indonesia, kalkulasi total harga barang bawaan harus disesuaikan dengan batasan bebas Bea Masuk. Jika melebihi, sebaiknya disampaikan kepada calon pembeli sanggup tidaknya membayar Bea Masuk dan PDRI atas barang titipannya. Untuk ongkos jasa titip barang luar negeri biasanya disepakati diawal antara calon pembeli dengan pelaku jasa titip. Besaran nilai relatif, menyesuaikan dengan mudah tidaknya barang diperoleh. Rata-rata fee jastip luar negeri antara 10\% sampai dengan 20\% dari harga awal barang. Pemerintah pada dasarnya mendukung kegiatan perekonomian kreatif seperti jasa titip ini yang dapat menunjang kehidupan perekonomian masyarakat. Akan tetapi pemerintah memberikan himbauan untuk tetap memenuhi peraturan khususnya dalam bidang pajak karena dapat berpotensi merugikan Negara.

\section{Penutup}

Perkembangan e-commerce di Indonesia semakin pesat dan memiliki dampak positif bagi para pelaku usaha, konsumen, maupun masyarakat. Bagi pelaku usaha, e-commerce memiliki dampak positif berupa pengurangan biaya operasional dan dapat memperlebar pangsa pasar, sehingga keuntungan yang diperoleh dapat dimaksimalkan dan lebih mudah dalam hal pengembangan bisnis. Namun dalam segala lini kegiatan salah satunya dibidang perekonomian sebagai warga Negara yang taat dan tunduk terhadap ketentuan yang berlaku, seharusnya kita selalu mematuhi aturan-aturan yang berlaku salah satunya adalah aturan mengenai perpajakan. Pelaku jasa titip online sebagai salah satu profesi yang bergelut dibidang perekoomian tentu saja memiliki penghasilan yang diperoleh dari bisnisnya tersebut. Dalam Undang-Undang Nomor 36 Tahun 2008 yang menjadi objek pajak penghasilan adalah penghasilan, yaitu

${ }^{24}$ Ibid 
setiap tambahan kemampuan ekonomis yang diterima atau diperoleh Wajib Pajak, baik yang berasal dari Indonesia maupun dari luar Indonesia, yang dapat dipakai untuk konsumsi atau untuk menambah kekayaan Wajib Pajak yang bersangkutan, dengan nama dan dalam bentuk apa pun. Termasuk di dalamnya adalah imbalan berkenaan dengan jasa yang diterima atau diperoleh dari bisnisnya sebagai pelaku usaha jasa titip online. Dari pengertian diatas sudah jelas bahwasanya usaha jasa titip dapat dijadikan objek pajak karena adanya keuntungan yang diperoleh dari usahnya tersebut. Selain itu ada pengenaan pajak perlu dilakukan untuk melindungi produk-produk luar negeri, agar produk-produk Indonesia tidak kalah saing dengan produk luar negeri. Untuk pemaksimalan hasil pemungutan pajak dan memaksimalkan hasilnya perlu dilakukan pemungutan pajak yang sesuai dengan kemampuan dan penghasilan Wajib Pajak. Dalam hal ini pelaku usaha yang memiliki penghasilan dari kegiatannya sebagai jasa titip online sudah seharusnya dikenakan pemungutan pajak karena menganut asas keseimbangan dan keadilan dimana karyawan dan buruh yang melakukan kegiatan impor barang pun dikenakan pajak. Pemungutan pajak terhadap pelaku usaha jasa titip online ini harus didasarkan Undang-Undang sehingga bagi yang melanggar ketentuan pajak tersebut akan dikenakan sanksi.

\section{Daftar Pustaka}

Buku

Abdul Halim (2005), Bisnis E-Commerce, Yogyakarta: Pustaka Pelajar, halaman 10

Amir, (1996), Ekspor-Impor, Jakarta: Pustaka Binaman Pesindo, halaman 43

Sugianto, (2008), Pengantar Kepabeanan dan Cukai, Jakarta: Cikal Sakti, halaman 173

Suyanto Muhammad, (2003), Strategi Periklanan pada E-commerce Perusahaan Top Dunia, Yogyakarta: Penerbit Andi

Prasetyo Budi Widagdo, (2016), Analisis Perkembangan E-Commerce Dalam Mendorong Pertumbuhan Ekonomi Wilayah di Indonesia, Yogyakarta: Fakultas Geografi Universitas Gadjah Mada 
Journal articles:

Chacha Andira Sari, (2015), Perilaku Berbelanja Online di Kalangan Mahasiswi Antropologi Universitas Airlangga, Surabaya: Skripsi Fakultas Ilmu Sosial dan Ilmu Politik Universitas Airlangga http://journal.unair.ac.id/download-fullpapers-auna97cbdaabbfull.pdf

Hemiwati, (2013), Penerapan Pasal 1320 KUHPerdata Terhadap Jual Beli Secara Online (E-Commerce), Jurnal Ipteks Terapan, Vol 8 No 4

Zurifah Diana Sari, (2018), Analisis Fiqih Muamalah Terhadap Praktik Jasa Titip Beli Online, Surabaya: Skripsi Fakultas Syariah dan Hukum Universitas Islam Negeri Sunan Ampel Surabaya

World Wide Web:

Kompasiana Chandra Mulyadi (2014), 10 Peringkat Indonesia di Dunia. https:/ /www.kompasiana.com/mulyady1688/54f934b0a333112c048b4a1a /10-peringkat-indonesia-di-dunia. [Accessed October 15 2019]

Bisnis Indonesia, https:/ / koran.bisnis.com/read/20170614/432/662322/jasa-titip, [Accessed October 4 2019]

Hukum

Online, https://www.hukumonline.com/klinik/detail/lt50bf69280b1ee/perlindun gan-konsumen-dala-e-commerce/, [Accessed October 4 2019]

Forum Ortax Santoso, (2019), Usaha Jasa Titip Harus Bayar Pajak?, https:/ / ortax.org/ortax/ ?mod=forum\&page=show\&idtopik=79866 [Accessed October 15 2019]

Direktorat Jenderal Pajak Purnadi Anang, (2019), Mudah Menjadi Jasa Titip Profesional, Bagaimana Kewajiban Pajaknya?, https://www.pajak.go.id/id/artikel/mudah-menjadi-jasa-titipprofesional-bagaimana-kewajiban-pajaknya. [Accessed October 15 2019] 